PART 1

Rwanda 


\title{
Foreword-Rwanda Revisited: Genocide, Civil War, and the Transformation of International Law
}

\author{
Lieutenant-General the Honourable Romeo Dallaire \\ The Roméo Dallaire Child Soldiers Initiative
}

\section{Keywords}

Rwanda - genocide - UNAMIR

It has been more than a quarter of a century since I was appointed as the Commander of the United Nations Assistance Mission in Rwanda (UNAMIR). When I took on the task, I knew very little about the tiny country, located in the heart of Africa, just below the equator. At that point in history, the internet was nowhere nearly as developed as it is today, so my primary source of information on current events for the region came from the scant coverage that the country received in the media. To say the least, Rwanda was not a place that attracted much attention from the western world before 1994, and we had no indication that within five months of the mission's commencement we would find ourselves in the middle of genocide that was unprecedented in violence and intensity. Nor could we have foreseen that our small peacekeeping force would become part of what is now recognized as a major juncture in post-cold war history, law, and politics.

It is clear that when the United Nations was contemplating the creation of UNAMIR in the summer of 1993, it was optimistic that the mission would be short, conducted with little risk of casualties, and most importantly, inexpensive. In spite of numerous warnings that pointed to a resurgence of ethnic violence as early as August 1993, the Security Council pushed forward with its plan to deploy a lightly armed peacekeeping mission that was approximately fifty percent smaller than had been recommended. As reports of massacres and the threat of wider violence increased during the first few months of the mission, the United Nations ignored the numerous warnings, and when faced with irrefutable evidence of impending violence, forbade UNAMIR from taking decisive action to intervene. Rather than reinforcing UNAM IR as Rwanda spiraled 
into genocide, the Security Council reduced the size of the mission and deliberately chose to avoid using the word "genocide" to describe the ethnic massacres that were consuming an average of 8,00o lives per day. It was not until the genocide and civil war were concluded by the Rwandan Patriotic Army's victory in the middle of July 1994, that my beleaguered force began to be reinforced, and the true extent of the genocide became known. In the subsequent months and years, evidence of horrible atrocities entered the public record, as the International Criminal Tribunal for Rwanda brought the most notorious leaders of the genocide to justice. Although it was too little and too late for the hundreds of thousands who perished, the establishment of the ICTY signaled a turning point in international law, providing notice to those who engage in genocide and crimes against humanity that there would be no guaranteed impunity, and no safe refuge for perpetrators of such egregious violence.

It is my distinct pleasure to have been invited to write the foreword for this collection of articles. This work is the first of its kind, providing an examination of the Rwanda tragedy from a wide variety of contributors, including a former ambassador to the Security Council, persons who were on the ground as part of UNAMIR, prosecutors in the ICTR, and dedicated international law scholars and journalists who have spent decades studying Rwanda and the role United Nations played in dealing with the genocide; before, during and after. The articles provide unique insight into how and why the events of 1994 unfolded, and how those events have influenced post-cold war politics and the over-all development of international law.

The legacy of Rwanda is not just one of the failure of the international community to react. It is also a story of how the world can respond in a positive manner when it realizes that colossal errors made at all levels have contributed to catastrophe. To that end, the Rwandan tragedy has inspired reform and innovation in how the international community seeks to prevent and respond to mass atrocities, as well as how to support societies recovering from violent conflict. In many respects the development of doctrines such as the Responsibility to Protect; Transitional Justice; the Protection of Civilians; and the advancement of the Women, Peace and Security agenda, can trace their origins to the Rwandan calamity.

As I have stated so often, we cannot afford to tolerate egregious abuses of human rights or human security; nor can we turn a blind eye to racism and other forms of intolerance. As the second decade of the twenty-first century draws to a close, it is apparent that isolationism is on the rise and that the Security Council has been paralyzed by the self-serving political and strategic interests of its permanent members. The current situations in Syria, Myanmar 
and Yemen are glaring examples of the human price that is exacted in this environment.

This publication should serve as a reminder of what can happen when national self-interests trump the requirements of humanity. The genocide in Rwanda was preventable, and it could have been stopped in its tracks had the international community responded appropriately. The world has the capacity to intervene to prevent or stop humanitarian disasters; all we need is the leadership and will to do what is right. Peux ce que veux. Allons-y.

\section{Biography}

Lieutenant-General (Retired) The Honourable Roméo Dallaire was the Force Commander of the UN Assistance Mission for Rwanda (UNAMIR) in 1993 and 1994. His book, Shake Hands with the Devil: The Failure of Humanity in Rwanda, was awarded the Governor General's Literary Award for Non-Fiction in 2004. Since his retirement from the military, he has written and spoken extensively about humanitarian assistance and human rights. He has been a member of the UN Secretary General's Advisory Board on Genocide Prevention, founder of the Roméo Dallaire Child Soldiers Initiative and a member of the Canadian Senate. 